http://ojs.stikes-muhammadiyahku.ac.id/index.php/herbapharma

\title{
PENGARUH PERBEDAAN METODE MASERASI DAN REMASERASI KULIT PISANG NANGKA (Musa paradisiaca L.) TERHADAP PENAPISAN FITOKIMIA
}

\author{
Ryan Farhan Pebrian ${ }^{1}$, Marini $^{2}$, Sinta Partiwi \\ ${ }^{1,2}$ STIKes Muhammadiyah Kuningan \\ *E-mail : ryanfarhan8@gmail.com
}

\begin{abstract}
ABSTRAK
Kulit Pisang Nangka (Musa paradisiaca L.) mengandung senyawa kimia seperti alkaloid, fenol, tanin, flavonoid, dan saponin.Penelitian ini bertujuan untuk mengetahui metode ekstraksi yang lebih baik antara metode Maserasi dan Remaserasi pada Kulit Pisang Nangka (Musa paradisiaca L.) terhadap Penapisan Fitokimia. Kandungan senyawa tersebut memiliki khasiat sebagai Antibakteri dan Antioksidan. Jenis yang digunakan dalam penelitian ini, yaitu Uji Laboratorium dengan uji metabolit sekunder menggunakan Ekstrak Kulit Pisang Nangka (Musa paradisiaca L.) yang menggunakan pelarut Etanol 96\%, dengan perbedaan penggunaan metode ekstraksi antara Maserasi dan Remaserasi.Hasil identifikasi uji penapisan fitokimia dengan dua metode yang berbeda ini menghasilkan senyawa metabolit sekunder yang sama, yaitu: alkaloid, flavonoid, fenol, tanin, dan saponin. Sedangkan pada nilai rendemen ekstrak Kulit Pisang Nangka dari metode maserasi, diperoleh persentase nilai rendemen sebanyak $5,21 \%$, dan pada metode remaserasi sebanyak 5,64\%. Hasil dari analisis kualitatif dengan metode penapisan fitokimia menunjukkan bahwa metode ekstaraksi maserasi dan remaserasi tidak mempengaruhi kandungan senyawa kimia dalam tumbuhan tetapi mempengaruhi \% rendemen ekstrak yang dihasilkan.
\end{abstract}

Kata kunci: Etanol 96\%, Kulit Pisang Nangka, Maserasi, Penapisan Fitokimia, Remaserasi.

\begin{abstract}
Banana peel Jackfruit (Musa paradisiaca L.) contains chemical compounds such as alkaloids, phenols, tannins, flavonoids, and saponins. This study aims to determine which extraction method is better between Maceration and Remaceration methods on Banana Jackfruit Skin (Musa paradisiaca L.) against Phytochemical Screening. The content of these compounds has properties as Antibacterial and Antioxidant. The type used in this study, namely Laboratory Test with secondary metabolite test using Banana Jackfruit Peel Extract (Musa paradisiaca L.) using 96\% Ethanol solvent, with differences in the use of extraction methods between Maceration and Remaceration. The identification results of the phytochemical screening test with these two different methods produced the same secondary metabolites, namely: alkaloids, flavonoids, phenols, tannins, and saponins. While the yield value of the Banana Jackfruit Peel extract from the maceration method, obtained the percentage of the yield value as much as 5,21\%, and the remaceration method as much as 5,64\%. The results of the qualitative analysis using the phytochemical screening method showed that the maceration and remaceration extinction method did not affect the content of chemical compounds in plants but influenced the\% of extract yield produced.
\end{abstract}

Keywords: Ethanol 96\%, Jackfruit Banana Skin , Maceration, Phytochemical Screening, Remaceration. 


\section{PENDAHULUAN}

Pisang merupakan tanaman tropis yang istimewa dengan memiliki banyak kegunaan, mulai dari buah, batang, daun, kulit hingga bonggolnya. Pisang merupakan tumbuhan berdaun hijau besar memanjang dari suku Musaceae. Iklim tropis yang sesuai serta kondisi tanah yang banyak mengandung humus memungkinkan tanaman pisang tersebar luas di seluruh daerah di indonesia (Sonja, 2017).

Kulit pisang merupakan bahan buangan (limbah buah pisang) yang banyak jumlahnya. Pada umumnya kulit pisang belum dimanfaatkan secara nyata, hanya dibuang sebagai limbah organik saja atau digunakan sebagai makanan ternak seperti kambing, sapi, dan kerbau (Supriyanti, T. M. F. 2015). Menurut penelitian yang telah dilakukan, kulit pisang nangka mengandung senyawa kimia seperti alkaloid, fenol, tanin, flavonoid, dan saponin. Dimana kandungan senyawa tersebut memiliki khasiat sebagai antibakteri dan antioksidan (Nursanti A, 2018).

Metabolit sekunder aktif dari tanaman obat dapat menggunakan berbagai metode ekstraksi. Metode ekstraksi yang sering digunakan adalah maserasi, remaserasi, soxletasi, refluks dan perkolasi. Metode ekstraksi yang sering digunakan dalam penelitian adalah maserasi dan remaserasi. Alasan metode tersebut sering digunakan adalah perlakuan lebih sederhana karena tidak membutuhkan perlatan yang mahal, kandungan kimia dalam simplisia yang akan ditarik aman karena tidak menggunakan pemanasan. Kondisi percobaan seperti waktu ekstraksi, jenis pelarut dan sampel pelarut akan mempengaruhi efektivitas proses ekstraksi (Arista, 2020). Kandungan metabolit sekunder utama didapatkan dengan cara melakukan optimasi dalam proses pembuatan ekstrak. Metode ekstraksi adalah salah satu optimasi yang bisa dilakukan untuk menghasilkan kandungan metabolit sekunder utama. Banyaknya zat yang dapat tersari dapat dilihat dengan optimasi metode ekstraksi sehingga perlu dilakukan penelitian untuk membandingkan kandungan metabolit sekunder aktif pada ekstrak kulit pisang nangka dengan metode maserasi dan remaserasi. Salah satu metode yang digunakan untuk mengidentifikasi kandungan senyawa dari suatu tanaman adalah penapisan fitokimia (Roxb, 2012).

Penapisan fitokimia merupakan tahap pendahuluan yang dapat memberikan gambaran mengenai kandungan senyawa tertentu dalam bahan alam yang akan diteliti. Golongan senyawa yang terkandung dalam tanaman akan tergambar dari hasil Penapisan Fitokimia dengan pengamatan perubahan warna secara visual (Roxb, 2012). Oleh karena itu, dilakukan penelitian ini untuk mengetahui metode ekstraksi yang lebih baik antara metode Maserasi dan Remaserasi pada Kulit Pisang Nangka (Musa paradisiaca L.) terhadap Penapisan Fitokimia.

\section{BAHAN DAN METODE}

\section{Bahan}

Bahan yang digunakan dalam penelitian ini adalah Ekstrak Kulit pisang nangka (Musa paradisiaca L.) Etanol 96\%(PT. Hikam Abadi Indonesia), Metanol p.a (PT. Smart-Lab Indonesia), Pereaksi Dragendroff p.a (PT. Nitra Kimia), Pereaksi Mayer p.a (PT. Nitra Kimia), $\mathrm{FeCI}_{3}$, Kloroform p.a (PT. Smart-Lab Indonesia), Asam Asetat Anhidrat p.a (PT. Malinckrodt), Aquadest, $\mathrm{HCl} 2 \mathrm{~N}$ p.a (PT. Nitra Kimia), $\mathrm{H}_{2} \mathrm{SO}_{4}$ pekat p.a (PT. Malinckrodt), $\mathrm{NaOH} 10 \%$ p.a (PT. Nitra Kimia).

Alat

Alat yang digunakan dalam penelitian ini adalah Lumpang (Pamosroom), Timbangan analitik (New Tech), Kertas perkamen (Donga), Kain flannel (JahitMart), Maserator (Kedaung), Selotip (Daimaru), Blender (Maspion), Pipet tetes (Pyrex), Cawan porselen (Herma), Tabung reaksi (Herma), Waterbath (Memmert), Batang pengaduk (ROFA), Selotip (Pizen). 


\section{Lokasi Dan Waktu Penelitian}

Penelitian ini dilakukan di Laboratorium Sediaan Bahan Alam STIKes Muhammadiyah Kuningan pada bulan Maret 2021.

\section{Prosedur Penelitian \\ Pengolahan Sampel}

Kulit pisang nangka mentah (Musa paradisiaca L.) dikumpulkan dari penjual pisang yang berada di Kadugede, Kuningan, Jawa Barat.Kulit pisang nangka (Musa paradisiaca L.) yang sudah bersih kemudian dirajang dan dilakukan pengeringan dibawah sinar matahari sampai kering kemudian di haluskan menggunakan blender sampai menjadi serbuk kulit pisang nangka, kemudian timbang sebanyak 500 gram untuk digunakan dalam metode ekstraksi.

\section{Proses Ekstraksi : \\ Maserasi}

250 gram serbuk kulit pisang nangka (Musa paradisiaca L.) ditambahkan pelarut etanol $96 \%$ sebanyak $1000 \mathrm{~mL}$ dan dilakukan maserasi. Setelah seluruh serbuk direndam kemudian dilakukan pengadukan secara perlahan dan direndam selama 3 hari dengan dilakukan pengadukan. Maserat yang dihasilkan kemudian diuapkan di atas waterbath hingga ekstrak menjadi kental (Arista, 2020).

\section{Remaserasi}

250 gram serbuk kulit pisang nangka (Musa paradisiaca L.) dimaserasi dengan pelarut etanol $96 \%$ sebanyak $500 \mathrm{~mL}$. Secara perlahan sambil diaduk hingga pelarut merendam seluruh serbuk kemudian direndam selama 24 jam dengan dilakukan pengadukan. Remaserasi dilakukan sebanyak 2 kali. lalu maserat yang dihasilkan kemudian diuapkan di atas waterbath hingga ekstrak menjadi kental (Arista, 2020).

\section{Penapisan Fitokimia : \\ Uji alkaloid}

Uji alkaloid dilakukan dengan cara melarutkan ekstrak uji sebanyak 0,3 gram diuapkan diatas cawan porselen hingga didapatkan residu. Residu kemudian dilarutkan dengan $5 \mathrm{~mL} \mathrm{HCl}$ 2 N. Larutan yang didapat kemudian dibagi ke dalam 3 tabung reaksi. Tabung pertama ditambahkan dengan $\mathrm{HCl} 2 \mathrm{~N}$ yang berfungsi sebagai blanko. Tabung kedua ditambahkan pereaksi Dragendroff sebanyak 3 tetes dan tabung ketiga ditambahkan pereaksi Mayer sebanyak 3 tetes. Terbentuknya endapan jingga pada tabung kedua, dan endapan putih hingga kekuningan pada tabung ketiga menunjukkan adanya alkaloid (Jones et al., 2006).

\section{Uji Flavonoid}

Pemeriksaan golongan flavonoid dapat dilakukan dengan uji warna, yaitu fitokimia untuk menentukan senyawa golongan flavonoid dan uji adanya senyawa polifenol. ekstrak ditambahkan sebanyak 0,3 gram pereaksi $\mathrm{NaOH} 10 \%$ dan reaksi positif apabila terjadi perubahan warna yang spesifik (Harbone, 1987).

\section{Uji Fenol}

Uji ini dilakukan dengan mencampurkan 0,1 gram ekstrak kulit pisang dengan $15 \mathrm{~mL}$ air kemudian dididihkan selama 2 menit dan disaring. Untuk uji fenol, $6 \mathrm{~mL}$ filtrat ditambahkan $\mathrm{NaOH} 10 \%$ beberapa tetes. Terbentuknya warna merah menunjukkan adanya senyawa fenolik (Nursanti, 2018).

\section{Uji Tanin}

Uji tanin dilakukan dengan cara melarutkan ekstrak sampel sebanyak 0,3 gram kedalam metanol sampai sampel terendam semuanya. Kemudian ditambahkan 2-3 tetes 
larutan $\mathrm{FeCl}_{3} 1 \%$. Hasil positif tanin ditunjukkan dengan terbentuknya warna hitam kebiruan atau hijau (Sangi et al., 2008).

\section{Uji triterpenoid}

Uji triterpenoid dilakukan dengan cara diuapkan larutan uji sebanyak 2 gram. Residu yang diperoleh dilarutkan dalam $0,5 \mathrm{~mL}$ kloroform, lalu ditambahkan $0,5 \mathrm{~mL}$ asam asetat anhidrat. Selanjutnya, campuran ini ditetesi $2 \mathrm{~mL}$ asam sulfat pekat melalui dinding tabung tersebut. Bila terbentuk warna hijau kebiruan menunjukkan adanya sterol. Jika hasil positif yang diperoleh berupa cincin kecokelatan atau violet pada perbatasan dua pelarut, menunjukkan adanya triterpenoid (Jones et al., 2006)06:12-14).

\section{Uji Saponin}

Uji saponin dilakukan dengan cara memasukkan ekstrak sampel sebanyak 0,1 gram ke dalam tabung reaksi, kemudian ditambahkan akuades hingga seluruh sampel terendam, didihkan selama 2-3 menit, dan selanjutnya didinginkan, kemudian dikocok dengan kuat. Hasil positif saponin ditunjukkan dengan terbentuknya buih atau busa yang stabil dalam sampel uji (Sangi etal., 2008)

\section{Uji Steroid}

Uji steroid dilakukan dengan cara memasukkan ekstrak sampel sebanyak 0.1 gram ditambahkan 3 tetes asetat anhidrat kemudian 1 tetes $\mathrm{H}_{2} \mathrm{SO}_{4}$ pekat. Steroid ditunjukkan dengan adanya perubahan warna hijau (Arista,2020).

\section{HASIL DAN PEMBAHASAN}

\section{Determinasi Tanaman}

Kulit pisang nangka (Musa paradisiaca L.) diperoleh dari Kecamatan Kadugede. Kabupaten Kuningan. Provinsi Jawa Barat. Telah dilakukan Determinasi di Laboratorium Bahan Herbal Sekolah Tinggi IImu Kesehatan Muhammadiyah Kuningan dan telah terbukti bahwa tanaman yang diperoleh berasal dari jenis kulit pisang nangka (Musa paradisiaca L.) dan suku Musaceae.

\section{Hasil Rendemen Simplisia dan Ekstrak Kulit Pisang Nangka}

Kulit pisang nangka digunakan sebanyak 4000 gram diperoleh simplisia kering sebanyak 1655 gram dan di dapat hasil rendemen simpilisia (Rendemen 41,3\%) kulit pisang nangka kering ini memiliki karakteristik berwarna hitam kecoklatan, memiliki rasa kelat dan aroma yang kuat. Hasil ekstraksi diuapkan dengan menggunakan waterbath untuk menghilangkan pelarut alkohol $96 \%$ yang digunakan. Proses penguapan pelarut dilakukan sampai ekstrak kental kemudian dilakukan perhitungan rendemen dari ekstrak yang didapatkan. Hasil rendemen ekstrak kulit pisang nangka dari setiap pelarut, baik menggunakan metode ekstraksi maserasi maupun remaserasi.

Rendemen merupakan perbandingan antara ekstrak yang diperoleh dengan simplisia awal. Rendemen menggunakan satuan persen (\%), semakin tinggi nilai rendemen yang dihasilkan menandakan nilai ekstrak yang dihasilkan semakin banyak (Armando, 2009).

$$
\text { Rendemen Ekstrak }=\frac{\text { Bobot Ekstrak Pekat }(\mathrm{g})}{\text { Bobot Bahan Sampel }(\mathrm{g})} \times 100 \%
$$

Tabel 1. Rendemen Hasil Ekstrak

\begin{tabular}{cccc}
\hline Metode Ekstraksi & $\begin{array}{c}\text { Berat Simplisia } \\
\text { (gram) }\end{array}$ & $\begin{array}{c}\text { Berat ekstrak } \\
\text { (gram) }\end{array}$ & Rendemen (\%) \\
\hline Maserasi & 250 & 13,04 & $5,21 \%$ \\
Remaserasi & 250 & 14,10 & $5,64 \%$ \\
\hline
\end{tabular}




\section{Hasil Pengujian Penapisan Fitokimia}

Ekstrak yang dihasilkan dilakukan pengujian penapisan fitokimia untuk mengidentifikasi golongan senyawa metabolit sekunder dalam ekstrak tersebut. Dari serangkaian pengujian penapisan fitokimia ekstrak pada metode maserasi dan remaserasi tidak memiliki golongan senyawa triterpenoid dan steroid. Hasil pengujian penapisan fitokimia ekstrak kulit pisang nangka dari tiap pelarut, baik menggunakan metode ekstraksi maserasi maupun remaserasi.

Tabel 2. Hasil Pengujian Penapisan Fitokimia

\begin{tabular}{lcc}
\hline $\begin{array}{l}\text { Golongan } \\
\text { Senyawa }\end{array}$ & Maserasi & $\begin{array}{c}\text { Remasera } \\
\text { si }\end{array}$ \\
\hline Alkaloid & + & + \\
\hline Flavonoid & + & + \\
\hline Fenol & + & + \\
\hline Tanin & + & + \\
\hline Triterpenoid & - & - \\
\hline Saponin & + & + \\
\hline Steroid & - & - \\
\hline Keterangan: & &
\end{tabular}

Keterangan :

$(+)=$ Terdeteksi

$(-)=$ Tidak Terdeteksi

Tabel 3. Hasil Uji Penapisan Fitokimia Metode Maserasi

\begin{tabular}{|c|c|c|c|}
\hline No & $\begin{array}{l}\text { Golongan } \\
\text { senyawa }\end{array}$ & Hasil & Keterangan \\
\hline \multirow[t]{5}{*}{1.} & Alkaloid: & & \\
\hline & - & + & Terjadi perubahan warna menjadi \\
\hline & Dragendroff & & jingga \\
\hline & & - & Terjadi perubahan \\
\hline & - Mayer & & $\begin{array}{c}\text { Tidak terbentuk endapan putih } \\
\text { hingga kekuningan }\end{array}$ \\
\hline 2. & Flavonoid & + & $\begin{array}{l}\text { Terjadi perubahan warna menjadi } \\
\text { warna kecoklatan }\end{array}$ \\
\hline 3. & Fenol & + & $\begin{array}{c}\text { Terjadi perubahan warna menjadi } \\
\text { warna merah }\end{array}$ \\
\hline 4. & Tanin & + & $\begin{array}{c}\text { Terjadi perubahan warna menjadi } \\
\text { warna hijau kehitaman }\end{array}$ \\
\hline 5. & Triterpenoid & - & $\begin{array}{l}\text { Terjadi perubahan warna menjadi } \\
\text { warna hitam diantara pembatas } 2 \\
\text { larutan }\end{array}$ \\
\hline 6. & Saponin & + & $\begin{array}{c}\text { Terjadi bentuk busa atau buih pada } \\
\text { laurtan }\end{array}$ \\
\hline 7. & Steroid & - & $\begin{array}{l}\text { Terjadi perubahan warna menjadi } \\
\text { warna hitam kemerahan }\end{array}$ \\
\hline
\end{tabular}

Keterangan :

$(+)=$ Terdeteksi

$(-)=$ Tidak Terdeteksi 
Tabel 4. Hasil Uji Penapisan Fitokimia Metode Remaserasi

\begin{tabular}{|c|c|c|c|}
\hline No & $\begin{array}{l}\text { Golongan } \\
\text { senyawa }\end{array}$ & Hasil & Keterangan \\
\hline 1. & $\begin{array}{l}\text { Alkaloid: } \\
\text { - } \\
\text { Dragendroff } \\
\text { - Mayer }\end{array}$ & + & $\begin{array}{c}\text { Terjadi perubahan warna menjadi } \\
\text { jingga } \\
\text { Terjadi perubahan } \\
\text { Tidak terbentuk endapan putih } \\
\text { hingga kekuningan } \\
\end{array}$ \\
\hline 2. & Flavonoid & + & $\begin{array}{l}\text { Terjadi perubahan warna menjadi } \\
\text { warna kecoklatan }\end{array}$ \\
\hline 3. & Fenol & + & $\begin{array}{l}\text { Terjadi perubahan warna menjadi } \\
\text { warna merah }\end{array}$ \\
\hline 4. & Tanin & + & $\begin{array}{l}\text { Terjadi perubahan warna menjadi } \\
\text { warna hijauan }\end{array}$ \\
\hline 5. & Triterpenoid & - & $\begin{array}{l}\text { Terjadi perubahan warna menjadi } \\
\text { warna hitam diantara pembatas } 2 \\
\text { larutan }\end{array}$ \\
\hline 6. & Saponin & + & $\begin{array}{l}\text { Terjadi bentuk busa atau buih pada } \\
\text { laurtan }\end{array}$ \\
\hline 7. & Steroid & - & $\begin{array}{l}\text { Terjadi perubahan warna menjadi } \\
\text { warna hitam keunguan }\end{array}$ \\
\hline
\end{tabular}

Keterangan :

$(+)=$ Terdeteksi

$(-)=$ Tidak Terdeteksi

Uji penapisan fitokimia yang telah dilakukan membuktikan bahwa kulit pisang nangka ini memiliki kandungan metabolit sekunder seperti alkaloid, flavonoid, fenol, tanin, dan saponin sesuai dengan penelitian yang telah dilakukan sebelumnya oleh Nursanti A, 2018. Namun pada penelitian ini terdapat hasil yang berbeda pada penggunaan pereaksi meyer dengan tidak terjadinya perubahan warna yang sesuai dengan prosedur. Hal ini bisa di sebabkan karena pereaksi yang sudah tercampur dengan bahan lain atau alat yang digunakan tidak steril. Dan ada Penelitian ini data rendemen hasil ekstraksi menunjukkan perbedaan hasil rendemen, baik metode maserasi atau metode remaserasi. Pada Tabel 1 menunjukkan bahwa metode estraksi secara remaserasi menghasilkan rendemen yang lebih tinggi dibandingkan dengan metode ekstraksi maserasi dapat menarik lebih maksimal senyawa biokatif padi kulit pisang nangka. Dengan hasil rendemen metode ekstraksi remaserasi sebesar $5,64 \%$ sedangkan rendemen dengan menggunakan metode ekstraksi maserasi sebesar 5,21\%.

\section{SIMPULAN}

Berdasarkan hasil data dapat disimpulkan bahwa perbedaan metode ekstraksi, memberikan pengaruh terhadap hasil rendemen ekstraksi kulit pisang nangka (Musa paradisiaca L.). Metode ekstraksi remaserasi memberikan hasil \% rendemen yang lebih besar yaitu 5,64\%, dibandingkan dengan metode ekstraksi maserasi yaitu 5,21\%. Namun, perbedaan metode ekstraksi tidak mempengaruhi dalam penarikan terhadap senyawa metabolit sekunder pada tanaman. Hasil uji kualitatif melalui penapisan fitokimia terhadap sampel kulit pisang nangka (Musa paradisiaca L.) menunjukkan bahwa sampel tersebut positif memiliki kandungan senyawa metabolit sekunder yang sama, baik menggunakan metode maserasi maupun remaserasi yaitu seperti alkaloid, flavanoid, fenol, tanin dan saponin. 


\section{REFERENSI}

Arista, W. 2020. Pengaruh Perbedaan Metode Ekstraksi Rimpang Kunyit (Curcuma domestica) Terhadap Rendemen dan Penapisan Fitokimia. Program Stusi S1 Farmasi STIKES RS ANWAR MEDIKA, Sidoarjo, Indonesia.

Armando, R. 2009. Memproduksi 15 Minyak Atsiri Berkualitas. Jakarta: Penerbit Penebar Swadaya

Harbone, J. 1987. Metode Fitokimia. Bandung: ITB.

Jones, W. P. 2006. Extraction of Plant Secondary Metabolites. In: Sarker, S.D., Latif,Z. and Jersey:Humana Press, P.341-342.

Nursanti. A. 2018. Aktivitas Antibakteri dan Uji Fitokimia Senyawa Metabolit Sekunder dari Limbah Kulit Pisang Kepok (Musa acuminata $x$ balbisiana), Kulit pisang Uli (Musa Paradisiaca Sapientum), dan Kulit pisang Nangka (Musa sp L). Jurusan Kimia UIN Alaiddin Makassar.

Roxb, Z. 2012. Skrining Fitokimia Ekstrak Mentanol Rimpang Bangle.

Sangi, M., Rumtuwene, M., \& Simbala, H. d. 2008. Analisis Tunbuhan Obat Di Kabupaten Minahasa Utara. Chemistry Progress, Vol.1, hlm:47-53.

Sonja. 2017. Uji Fitokimia Kulit Pisang Kepok (Musa Paradisiaca L.) Bahan Alam Sebagai Peptisida Nabati Berpotensi Menekan Serangan Serangga Hama Tanaman Umur Pendek. Pendidikan Biologi FKIP Universitas Mulawarman.

Supriyanti, T. M. 2015. Pemanfaatan Ekstrak Kulit Pisang Kepok (Musa paradisiaca L) Sebagai Sumber Antioksidan pada Produksi Tahu. Seminar Nasional Kimia dan Pendidikan Kimia VII UN. 